\title{
Verslaving, criminaliteit en resocialisatie
}

\author{
A. de Vries*
}

"De Werkgroep is van mening dat een geïntegreerd behandelplan, waarin zowel aandacht wordt gegeven aan de verslavingsproblemen als aan de persoonlijkheidsproblemen, de meeste kans van slagen heeft (...). De werkgroep is van mening dat het niet noodzakelijk is aparte programma's voor de behandeling van verslaving en persoonlijkheidsproblematiek toe te passen (...). Het verdient de aanbeveling een geïntegreerde behandeling aan te bieden."

(Multidisciplinaire Richtlijn voor Persoonlijkheidsstoornissen - 23 april 2008)

\section{FVK Piet Roordakliniek}

De Piet Roordakliniek is een forensische verslavingskliniek (FVK) en biedt behandeling aan cliënten die veelvuldig met justitie in aanraking zijn gekomen, langdurig verslaafd zijn en niet in staat zijn om dit patroon te doorbreken. De cliëntengroep in deze kliniek kenmerkt zich door problematiek op verschillende gebieden, namelijk persoonlijkheidsproblematiek (met name antisociale persoonlijkheidsstoornis), verslaving, criminaliteit en psychiatrische problematiek. De Piet Roordakliniek biedt behandeling aan deze groep cliënten door middel van een geïntegreerde benadering, waarbij gelijktijdig aandacht is voor de verschillende problematieken. De kliniek bestaat uit twee locaties. Locatie Apeldoorn biedt een besloten setting, met de mogelijkheid tot het werken naar een open setting en doorstroom naar resocialisatie. Locatie Beneden Leeuwen biedt een open setting, veelal als vervolgbehandeling na verblijf in Apeldoom en doorstroom naar resocialisatie. Het totale traject biedt plaats aan ongeveer 60 cliënten.

* Agnes de Vries is voorlichtster van de Piet Roordakliniek voor Forensische Verslavingszorg (Tactus). 
"Als ik voor iets ga, dan ga ik er ook voor. En niet zo halverwege. In het verleden heeft me dit ook wel eens problemen opgeleverd, maar hier is het goed juist." (cliënt FVK)

\section{Behandelaanbod}

Bij onze aanpak van verslaving en criminaliteit richten wij ons op vroegsignalering. Vroegsignalering is een methodiek waarbij gezocht wordt naar signalen die opvolgend gedrag kunnen voorspellen. In de behandeling nodigen we cliënten uit om als een buitenstaander te leren kijken naar eigen gedrag. Gedrag herhaalt zich en vertoont in de praktijk vaak dezelfde voorafgaande stappen. Stappen waar cliënten zich vaak niet van bewust zijn. Het leren herkennen van eerste veranderingen in gedachten, gevoelens en gedrag is de basis voor een signaleringsplan. In het signaleringsplan worden de signalen vastgelegd en voorzien van acties die de cliënt kan inzetten om risicosituaties te voorkomen. Met dit plan proberen we te helpen bij het bijtijds herkennen van verhoogde risicosituaties. Vervolgens spreken wij cliënten aan op de verantwoordelijkheid om in dit soort situaties te zoeken naar een oplossing zonder middelengebruik en criminaliteit. De praktijk leert dat met het aangaan van contacten buiten de kliniek, mensen in de omgeving meehelpen bij het herkennen van de eerste stappen van een terugval.

"Ik ben nu 39 maanden overal vanaf en dan is het moeilijk om je weer voor te gaan stellen hoe dat ook al weer allemaal was. Moet wel, maar dat is moeilijk. Ik wil het liever achter me laten, maar dan ben je misschien minder bewust van de risico's." (cliënt FVK)

Eigen aan verslaving is de trek. In het begin proberen we cliënten te helpen met zelfcontrole. Vanuit de persoonlijkheid van de cliënt houden we rekening met de doorgaans aanwezige ongevoeligheid voor straf, moeite met autoriteiten en onrecht. Wij richten ons op het belonen van gewenst nieuw gedrag. Gedrag dat nodig is om weer in de maatschappij een eigen leven te kunnen leiden. Nadat de cliënt door middel van een risicoanalyse en een signaleringsplan voldoende controle heeft bereikt, wordt dit beloond door te werken met vrijheden en activiteiten buiten de kliniek. Vrijheden zijn enerzijds beloning, maar betekenen in de praktijk tegelijkertijd oefenen met verslavingsproblematiek en deze informatie gebruiken we om een actueel signaleringsplan op te stellen. Terugval in gebruik is in zekere zin onderdeel van onze behandeling. Wij hebben zeker geen gedoogbeleid, maar we accep- 
teren dat een terugval bij een behandeling hoort. Het is de bedoeling dat de cliënt leert om in geval van terugval het gebruik beperkt te houden en niet opnieuw in de criminaliteit te belanden.

'Bij het leren van nieuw gedrag kan er zelfs vaak van uitgegaan worden dat circa 90\% van de personen niet in staat is om gedragsverandering te bereiken bij hun eerste poging.' (Polivy \& Herman, 2002).

Wij hebben een gestructureerd en ondersteunend behandelklimaat. Duidelijkheid, voorspelbaarheid, openheid, dagritme en leren in de groep van elkaar, zijn voor ons belangrijke uitgangspunten. Doorgaans is binnen een aantal maanden de persoonlijke rust teruggekeerd en richt de cliënt de blik op de toekomst. Wij zien vaak een goed herstel van functioneren, vooral op het terrein van dagbesteding en sociale contacten. Wel is er nog toezicht en begeleiding nodig. Het afbouwen van een besloten naar een open behandelsetting is de eerste stap. Vervolgens wordt vanuit een open afdeling toegewerkt naar een vorm van (beschermd) wonen. In het gehele traject blijft de vroegsignaleringsmethodiek centraal staan. Openheid en zicht hebben op de persoonlijke verslavings- en delictketen zijn belangrijk om de omgeving te overtuigen dat de cliënt weer te vertrouwen is. Doordat veel cliënten in de regio willen blijven hebben we inmiddels een intensieve samenwerking met het RIBW (Regionale Instelling voor Beschermd Wonen) en de gemeente.

“...ik heb het jarenlang verprutst, ik had mogelijkheden zat maar ik had weinig zin. Ik heb nu zin om iets te gaan doen met het leven. Ik heb een uitdaging nodig, een doel is belangrijk. Dat je iets doet om nuttig te zijn."

(cliënt FVK)

\section{Indicatiestelling}

"Ik heb gebruikt vanaf mijn $16^{e}$ en soms dan denk ik van, waar heb ik al die tijd gezeten joh. Wat heb ik gedaan toen eigenlijk?"

(cliënt FVK)

\section{Cliënttypering}

Vanuit de Effectevaluatie van de FVK (AIAR, 2007) wordt bijna driekwart van de cliënten met verslavingsproblematiek en antisociale persoonlijkheid gekenmerkt. Dit is niet verwonderlijk vanuit de ervaring dat ernstige verslavingsproblematiek vaak aanleiding geeft tot criminaliteit. Dit sluit ook aan 
bij de toenemende aanwijzingen dat voor antisociaal gedrag, verslaving en psychotische kwetsbaarheid een gemeenschappelijke erfelijke factor bestaat. Omdat de stoornissen naast elkaar voorkomen hebben wij gekozen voor een integrale aanpak waarbij de stoornissen gelijktijdig worden behandeld. De forensische verslavingskliniek heeft hiermee zijn beide herkenbare pijlers in zijn specifieke aanpak gericht op criminaliteit en verslaving. Wij hechten er grote waarde aan bestaande wetenschappelijk onderbouwde richtlijnen zo veel mogelijk te volgen.

Persoonlijkheidsproblematiek is doorgaans een langer bestaand patroon van gedrag, denken en gevoelens waardoor mensen geleidelijk vast lopen in de omgang met anderen. Bij antisociale problematiek gaat het om mensen die problemen met hun omgeving hebben. Mensen lijden vaak onder het gemis aan sociale aansluiting en het moeilijk vast kunnen houden van relaties en werk. Een behandeling betekent niet alleen afleren van een leefstijl met middelen, maar ook op nieuw aansluiting zoeken in de samenleving en deze vasthouden.

"Ik ben bezig om een ander sociaal netwerk op te bouwen met ander soort mensen. Anders is het lastig als je elke dag weer in de gebruikerswereld zit, dat is niet goed." (cliënt FVK)

Onze cliënten hebben vaak al vanaf vroege leeftijd problemen met de politie en verslaving. Vaak zijn ze na jaren vastgelopen in een vicieuze cirkel van verslaving, criminaliteit en psychiatrische symptomen, als bijvoorbeeld paranoia, impulsiviteit, en ontremming. In onze visie is de cirkel van gebruik en criminaliteit het best te stoppen door te kiezen voor een nieuwe start waarin wonen en werken centraal staan. Dat betekent dat wij het belangrijk vinden dat mensen goed leren communiceren met hun omgeving en meer controle over hun eigen gevoelswereld leren krijgen.

"Ik had moeite altijd om mensen aan te spreken op hun gedrag en dat doe ik nu wel. Als ik iets niet leuk vind of zo dan vertel ik het op een normale manier, zeg maar. Ik merk dat mensen er goed mee omgaan en dat het ook oplucht, als je het vertelt meteen. Durf te hebben om het zelf te doen."

(cliënt FVK)

\section{Criminaliteit en verslaving}

Wij zijn er voor cliënten waarbij er een verband is tussen langdurig gebruik en criminaliteit. Vaak zien wij in de voorgeschiedenis de nodige problemen 
in de jeugd en al contacten met de politie voor de verslaving is ontstaan. Internaten en eerdere hulpverlening in de voorgeschiedenis zijn eerder regel dan uitzondering. Wij richten ons vooral op cliënten die van 'kleine' criminaliteit door gebruik naar ernstige vormen van criminaliteit zijn gegaan. Daar waar de rem door gebruik er vanaf gegaan lijkt te zijn. Hierbij is er dus altijd sprake van een verband tussen verslaving en criminaliteit. Bij deze groep is onze aanpak om naast het werken aan jezelf, te werken aan de omgeving. Een omgeving zonder gebruik en criminaliteit helpt bij het loslaten van de oude leefstijl. In onze visie moet je bij grenzen in leerbaarheid eerst kijken naar de mogelijkheden in je omgeving om je te helpen. Vanuit deze visie valt te begrijpen dat hierin ook de grenzen liggen van onze behandeling. Zo laten wij geen mensen toe die eerst in de georganiseerde criminaliteit hebben gezeten of waarbij gebruik nauwelijks een rol speelt. Daarnaast hebben wij voor behandeling bij zedendelicten geen aanbod in verband met de specifieke deskundigheid die nodig is voor behandeling van deze problematiek. Als het gaat om de psychiatrische klachten, kijken wij of de criminaliteit samenhangt met ernstige stoornissen als schizofrenie of manisch depressiviteit. In die gevallen zijn mensen beter af met een (meer beveiligde, op de psychiatrie gerichte) behandeling elders. Zwakbegaafdheid hoeft geen reden voor afwijzing te zijn. In dat geval kijken wij naar eventuele moeite met autoriteiten, de sociale vaardigheden in de groep en de motivatie om toe te werken naar beschermde woonomgeving. Toewerken naar een toekomstige woonomgeving met een beschermend karakter ligt in de praktijk voor velen voor de hand.

'Daar waar herstel van de autonomie niet volledig mogelijk is, dient de behandeling erop gericht te zijn de leefomgeving zo in te richten, dat door de inzet van steunsystemen op het gebied van sociaal netwerk, wonen en dagactiviteiten, de blijvende tekorten zo min mogelijk beperkingen opleveren.' (Elsenaar, Roozen, Hauptman, van de Wetering, 2007)

\section{Justitiële titels}

De start van een behandeling is onder paraplu van justitie. Justitie verwacht van onze cliënten dat ze in behandeling werken aan de beveiliging van zichzelf en hun omgeving. Wij zien het als een uitdaging om deze eis samen te laten vallen met een hulpvraag. Dit betekent werken in een drangkader, waarbij het zoeken naar de aansluiting bij de cliënt van groot belang is om tot een start van behandeling te komen. Zo proberen wij waar mogelijk aan te sluiten bij de mogelijkheden en persoonlijke voorkeuren van de cliënt. Wij kijken hierbij naar bestaande sociale contacten zonder gebruik of criminali- 
teit; bestaande sociale steun; het kunnen hanteren van eigen gevoelens in relaties en eerdere positieve ervaringen uit het verleden.

\section{Motivatie}

Motivatie is iets dat komt en gaat gedurende de gehele behandeling. In het begin is het de opluchting niet meer op straat te leven of niet in de gevangenis te hoeven zijn. Dit gevoel zakt echter al snel. Door al vroeg in de behandeling aan te sluiten bij contacten in de maatschappij gaat de aanvankelijke motivatie doorgaans over in het niet kwijt willen raken van wat is opgebouwd. Zo is een werkkring of een goed lopende omgangsregeling met de kinderen een belangrijke drijfveer om door te gaan. In iedere fase van motivatie vinden wij het belangrijk dat er gewerkt wordt aan het besef dat oud anti sociaal gedrag uiteindelijk ten koste gaat van het behouden van sociale contacten als werk en relaties.

"Ik doe het voor mezelf, innerlijke motivatie. Als je het doet voor iemand anders dan lukt het niet. Belangrijk is dat denk ik." (cliënt FVK)

\section{Literatuur:}

- Rapport Gezondheidsraad, Preventie en behandeling van de antisociale persoonlijkheidsstoornis, 8 mei 2006.

- Elsenaar, Roozen, Hauptman en Van de Wetering, Terugvalmanagement bij verslaving. 'Verslaving', nr. 3 (2007).

- Polivy, J., Herman, C.P., If at First you don't succeed. False hopes of self-change. American Psychologist (2002).

- Citaten van een cliënt, FVK Piet Roordakliniek Locatie Apeldoorn. 